standards, as when Buddhistic scruples prevent the Buddhist from raising silkworms.

Although the raising of edible plants usually spreads rapidly from one culture to another, it is not difficult to find exceptions. Why did rice fail to penetrate Oceania? Why do the contemporary Tahitians, with the example of the Chinese colonist before them, disdain to raise it ? Why did potato cultivation remain confined to Andean cultures in pre-Columbian times even though wild species occurred to the north ? Why did the tomato, a native of South America, reach the Ijca of northern Colombia only in recent times?

Though not all such instances are explainable, Dr. Lowie considers that a partial explanation is that borrowing of cultural traits is not likely to occur when the potential recipient possesses an adequate counterpart.

In discussing the influence of borrowed traits upon culture, Dr. Lowie pointed out that borrowed traits, because of their extreme novelty, seldom are accept. able to the religious aspects of a culture. He cited as examples the reluctance of American Indian tribes to accept horses and guns into their religious ritual and worship, long after both horses and firearms had been widely used by the tribe. The horse remained of little religious importance. Even though it was an object constantly prayed for, we rarely, if ever, hear of a supernatural horse on a par with the bear, eagle, beaver, or other animal spirits. One Crow band had a horse dance, but the celebrants believed that they derived their power from an eagle.

The principle that novelties are religiously inferior holds true for weapons as well. In 1805 the Crow, obliged to obtain firearms and ammunition from the village tribes of the upper Missouri, were still poor shots with the gun. The deficiency was soon overcome, and, what is more, the wresting of a gun in a hand-to-hand fight came to be recognized as an honorific exploit equivalent to the older bowsnatching. Yet in the preparations for the sacred sun dance it was explicitly ordained to shoot a bull without the use of a gun.

Dr. Lowie also referred to the Crow practice of beginning a war expedition on foot, out of respect for the ancient method of fighting, even though the warriors later mounted horses.

Prof. Rostovtzeff stated that while 'Hellenization' was effected among the well-to-do natives, it did not touch the masses of the population of the two monarchies, the peasants of the country and the artisans of the cities, towns, and villages.

In time, the Greeks became privileged servants of the king and soon a powerful bureaucracy grew up dominated by the Greek administrators. From the point of view of the masses, the Greeks were their oppressors. They extracted from them ever heavier taxes, they supervised their compulsory labour, they acted as agents of the Government in exercising an ever stricter control over their economic life. The native working classes complained to their protector, the king, but they soon found out that the kings were helpless to relieve their sufferings. The powerfully organized bureaucracy was stronger than the royal will. No wonder then from time to time the natives rose in revolt.

As the Greeks began to intermarry with Egyptians, Dr. Rostovtzeff declared, they became more and more influenced by Egyptian culture, and soon an 'Orientalized' type of Greek came into existence. The Greeks were gradually absorbed by their Oriental surroundings. Climate, food, environment had their natural effects. A new type was in formation. Wo know little of this type, but its existence is crrtain.

It is significant, for example, how rapidly the Greeks became 'Orientalized' in religion. From the very beginning they worshipped in Fgypt the new 'Hellenized' god Sarapis, a blend of the Egyptian Osiris and certain Greek gods. They became more and more devoted to this god as time went on, and especially to his divine consort the mighty Isis, long familiar to the Greeks. There was also the growing devotion of the Egyptian Greeks to the various animal gods such as the great crocodile god, and to the pseudo-science of astrology.

Another symptom of 'Orientalization' was the gradual change in the spirit of the Greeks. The buoyant energy of the pioneers of the third century B.c., their creative force, gradually subsided. Creation was replaced by routine, the Greek tempo of work was followed by Oriental passivity.

By the time of the rise of Roman power, Dr. Rostovtzeff said, the Greek creative force in Egypt had been exhausted and Egypt and the entire Greek world became incorporated into the Roman Empire.

\title{
THE QATTARA DEPRESSION
}

\section{By M. G. BEADNELL}

$\mathrm{T}$ HE account in NATURE of November 1 of the career of the late Dr. John Ball, technical adviser to the Geological Survey Department of Egypt, brings vividly before me his enthusiasm on the subject of the Qattara Depression Scheme, with which his name was so closely associated in Egypt.

Roughly speaking, the depression is shaped like an elongat 3 mutton-cutlet, and has a total superficial area of $19,500 \mathrm{sq} . \mathrm{km}$., two thirds of which are more than 50 metres below sea-level, and the remainder reaching a minimum of $-134 \mathrm{~m}$. at a point southeast of the tiny enclosed Oasis of Qara. Its greatest length, from west to east, is $298 \mathrm{~km}$., and greatest breivlth, from north to south, $145 \mathrm{~km}$. The depres- sion extends from nearly $80 \mathrm{~km}$. from Siwa on the west to within $205 \mathrm{~km}$. of Cairo on the east, and its most northerly boundary is only $56 \mathrm{~km}$. from the Mediterranean.

Nearly a third of the floor consists of a damp mixture of sand, clays and salts, known as "Sabakha", an Arabic term applied to deposits having a fertilizing value. (This area is so enormous that a proposal was put forward at the time by a Cairo newspaper that the depression should be exploited for its economic value, as a parallel to that of the Dead Sea, but this was never undertaken.)

The existence of this low-lying tract was discovered only in 1917, and quite fortuitously. The 
commander of a military patrol going through that part of Northern Libya was requested by the Survey of Egypt to take aneroid readings, and the result was so surprising that at the earliest opportunity a scientific surveying party was sent there to confirm the data obtained. This led to a visit to the region by Hussein Sirry Bey (now Prime Minister), at that time director-general of the Survey Department, accompanied by Dr. Ball, director of the Desert Surveys branch.

There and then was conceived the huge project of bringing the water of the Mediterranean to the depression through a $60-\mathrm{km}$. aqueduct, part canal and part tunnel, and utilizing its fall from the exit -about $250 \mathrm{~m}$. below the summit of the escarpmentfor the generation of electric power on an enormous scale. They calculated that evaporation would effectively prevent the resulting lake from rising to the level of the site of the power-station.

This scheme appealed immensely to the people of Egypt -always worshippers of everything on a grand scale-for they immediately saw a navigable canal connecting the sea with a vast lake over which they might sail almost to Siwa, as well as a natural and inexhaustible electrical supply of 250-350,000 kw., providing cheap power and light for the towns and villages of the Delta.

After some experimental outlay on ascertaining the nature of the strata to be excavated, the idea was entirely abandoned, as its cost would have been prohibitive and exhausted the exchequer before any returns could reasonably be expected.

A point of considerable interest is that in the Miocene and later beds of the 300-metre escarpment of Qattara, a discovery was made of fossil bones of prehistoric animals, descendants of the Eocene Arsinoitherium Zittelli and contemporary ancestors of the elephant, excavated nearly forty years ago in the Fayum Province of Egypt. Owing to stress of work, this find could not be investigated, and is known only to the finder.

Qattara is the starting-point of many of the sanddune belts of the Libyan Desert. Wind-erosion is persistently disintegrating the clays, sandstones and limestones out-cropping on the face of the escarpment, the grains being unceasingly swept away and blown southwards to add to the ever-increasing volume of these dunes, the most deadly obstacles to the domination of the desert yet encountered by man.

\section{FORTHCOMING EVENTS}

\author{
MONDAY, DECEMBER 15 \\ ROYAL GEOGRAPHICAL SocIETY (at Kensington"Gore, London, S.W.7), \\ at 3 p.m.-Mr. J. W. Crowfoot: "Syria".
}

\section{TUESDAY, DECEMBER 16}

ROYAL SOCIETY OF ARTS (DOMINIONS AND CoLONIES SECTION) (at John Adam Street, Adelphi, London, W.C.2), at 1.45 p.m.-Dr. Maurice Ashby: "British Empire Drugs Production".

ROYAL Institution of GREAT BRITAIN (at 21 Albemarle Street, London, W.1), at 2.30 p.m.- Prof. J. C. Drummond: "Recent War-Time".

\section{THURSDAY, DECEMBER 18}

ROYAL INSTITUTION OF GREAT BRITAIN (at 21 Albemarle Street, London, W.1), at 2.30 p.m.-Sir John Russell, F.R.S.: "Collective Farming in Russia and the Ukraine".

INSTITUTION OF ELECTRICAL ENGINEERS (at Savoy Place, Victoria Embankment, London, W.C.2), at 5 p.m.-Dr. W. G. Radley and Mr. E. P. G. Wright: "Voice-Frequency Signalling and Dialling in Long-Distance Telephony".

\section{APPOINTMENTS VACANT}

APPLICATIONs are invited for the following appointments on or before the dates mentioned:

LECTURER IN ENGINEARING-The Clerk to the Governors, SouthEast Essex Technical College, Longbridge Road, Dagenham (December 17). Assistant Lecturer in Mathematics at the Brighton Technical
College-The Education Officer, 54 Old Steine, Brighton 1 (December 19).

Lecturer in Electrioal Engineering at the Hull Municipal Technical College-The Director of Education, Guildhall, Hull (December 22).

Head of the Mechanical Enginegring Department of the Rutherford Technical College-The Director of Education, City Education Office, Northumberland Road, Newcastle-upon-Tyne 2 (December 27).

Eddcation Psychologist (man or woman) and a Psychiatric SOCIAL WORKER (woman)-The Director of Education, City Education ELECTRICAI ENGINEER by the Nigerian Government Public Works Department-The Crown Agents for the Colonies, 4 Millbank, London, Department-The Crown
S.W.1 (quoting $M / 9422$ ).

Engrnere by the Hong Kong Government Public Works Department-The Ministry of Labour and National Service, Central Register Branch, Queen Anne's Chambers, Tothill Street, London, S.W.1 (quoting E.352).

\section{REPORTS AND OTHER PUBLICATIONS}

(not included in the monthly Books Supplement)

Great Britain and Ireland

Eire: Roinn Talmhaidheachta (Department of Agriculture) : Brainse Iascaigh (Fisheries Branch). Report on the Sea and Inland Fisheries for the Year 1939. (P. No. 4657.) Pp. 30. (Dublin:
Stationery Office.) 6d.

B, No. 6: Salmon of the Oroyal Irish Academy. Vol. 47, Section B, No. Went. Pp. 161-178. (Dublin: Hodges, Figgis and Co., Ltd.; London : Williams and Norgate, Ltd.) 18.

\section{Other Countries}

Canada : Department of Mines and Resources, Mines and Geology Branch : Bureau of Geology and Topography, Geological Survey. Memoir 226: Palæozoic Geology of the Brantford Area, Ontario. By J. F. Caley. (No. 2458.) Pp. iv +176. 50 cents. Memoir 227: By F. J. Alcock. (No. 2459.) Pp. iv +46. 25 cents. Memoir 230: Mineral Industry of the Northwest Territories. By C. S. Lord. (No. 2462.) Pp. vi 136. 50 cents. Paper 40-18: Report and Preliminary Map, Houston Map-Area, British Columbia. By A. H. Pang. Pp. iii $+18+$ map. 10 cents. Paper 41-5: Preliminary Map, Manson Creek, British Columbia. By A. H. Lang. 10 cents. Paper 41-6: Vassan-Dubuisson Map Area, Abitiki County, Quebec (Summary County, Quebec (Summary Account). By E. D. Kindle. Pp. iil +5 + map. 10 cents. Paper 41-8: Preliminary Map, Morley, Alberta. By G. S. Hume and H. H. Beach. 10 cents. Paper 41-9: Preliminary Map, Bighorn River, Alberta. By B. R. Mackay. 10 cents. Paper 41-11 : Preliminary Map, Redcliff, Alberta. By J. S. Stewart.
10 cents. (Ottawa : King's Printer.) U.S. Department of the Interior : Geological Survey. Bulletin 908: Geology of Area between Green and Colorado Rivers, Grand and San Juan Counties, Utah. By Edwin F. MeKnight. Pp. v+147+13 plates. 1.50 dollars. Bulletin 910-C : Fineness of Gold from Alaska Placers. By Philip S. Smith. (Mineral Resources of Alaska, 1937.) Pp. vi $+147-272+$ plate 3.30 cents. Bulletin 911 : Ore Deposits in the Vicinity of the London Fault of Colorado. By Quentin D. Singewald and $B$. S. Butler. Pp. vi $+74+21$ plates. 1.50 dollars. Water-Supply Paper 848 : Ground Water in Keith County, Nebraska. By Leland $K$. Wenzel and Herbert $A$. Waite; with Sections on Platte Valley Public Power and Irrigation District, Sutherland Project, by E. E. Halmos, and Central Nebraska Public Power and Irrigation District, Tri-County Project, by G. E. Johnson. Po. iv $+68+8$ plates. 70 cents. Water-Supply Paper 869 : Flood of August 1935 in the Muskingum River Basin, Ohio. By C. V. Youngauist and W, B. Langbein; with Sections on the Associated Meteorology and Hydrology, by Waldo E. Smith and A. K. Showalter. Pp. vi $+118+8$ plates. 40 cents. Water-Supply Paper 885 : Surface Water Supply (Washington, D.C.: Government Printing Office.)

Editorial and Publishing Offices
MACMILLAN \& CO., LTD.,
ST. MARTIN'S STREET, LONDON, W.C.2.
Telephone: Whitehall 883I Telegrams: Phusis Lesquare London
Advertisements should be addressed to
T. G. Scott \& Son, Ltd., Three Gables, London Road, Merstham, Surrey
Telephone : Merstham 316
All rights reserved. Registered as a Newspaper at the General Post Office 